UDC 338.45:616.2:613.6.02

DOI: $10.21668 /$ health.risk/2017.3.10.eng

\title{
RISK OF DUST BRONCHOPULMONARY PATHOLOGY DEVELOPMENT IN WORKERS EMPLOYED IN VARIOUS ECONOMIC BRUNCHES UNDER IMPACTS EXERTED BY OCCUPATIONAL RISK FACTORS: CLINICAL AND HYGIENIC ASPECTS
}

\author{
A.B. Bakirov ${ }^{1}$, S.R. Mingazova ${ }^{1}$, L.K. Karimova ${ }^{1}$, P.V. Serebryakov ${ }^{2}$, \\ G.F. Mukhammadieva ${ }^{1}$ \\ ${ }^{1}$ Ufa Research Institute of Occupational Health and Human Ecology, 94 Stepana Kuvykina Str., Ufa, 450106, \\ Russian Federation \\ ${ }^{2}$ F.F. Erisman Federal Scientific Centre of Hygiene, 2 Semashko Str., Myitishchi, Moscow Region, 141014, \\ Russian Federation
}

We performed complex clinical and hygienic research on 234 workers suffering from occupational bronchitis; they were employed in petrochemical industry, mining, civil engineering, as well as in construction. Group of workers with occupational diseases comprised hose suffering from dust bronchitis and toxic-dust bronchitis. Workers employed in the examined branches had to work under exposure to production aerosols with complex structure and they working conditions had 3.2-3.4 hazard degree. We showed that occupational factors exerted negative influence on workers' health as they caused occupational bronchitis development, grave complications, and frequent associated diseases evolvement. The paper dwells on the results of our research on lipid peroxidation products content in workers exposed to production aerosols. We detected increased activity of free radical oxidation caused by impacts exerted by production aerosols; here we revealed that growth in lipid peroxidation products depended on duration of work under hazardous conditions. We set a goal to detect correlation between polymorph gene types of xenobiotics transformation enzymes and occupational bronchitis evolvement via polymerase chain reaction technique; to achieve this, we analyzed polymorphic locuses in a group of sick workers (131 people) and healthy ones (156 people). We determined genetic markers which had protective significance in terms of occupational bronchitis evolvement risk. The research results prove that occupational bronchitis nature and peculiarities of its clinic picture are determined both by occupational impacts and individual features of a worker's body.

Key words: working conditions, risk factors, production aerosols, workers, occupational bronchitis, health state, health parameters, xenobiotics transformation genes.

Today occupational diseases of the respiratory tract which occur at industrial enterprises are a great medical and social challenge as they are widely spread and do substantial economic damage due to persistent temporary disability of qualified staff $[2$, 4].

"Dust" diseases are multi-factor ones as they are caused by complex impacts exerted by environmental and genetic factors $[5,6$,

(C) Bakirov A.B., Mingazova S.R., Karimova L.K., Serebryakov P.V., Mukhammadieva G.F., 2017

Akhat B. Bakirov - Doctor of Medical Sciences, Professor, Director (e-mail: fbun@uniimtech.ru; tel.: + 7 (347) 255-19-57).

Svetlana R. Mingazova - Candidate of Medical Sciences, a physician at Occupational Allergology and Immune Rehabilitation Department (e-mail: iao_karimova@rambler.ru; tel.: + 7 (347) 255-57-21).

Liliya K. Karimova - Doctor of Medical Sciences, Professor, Chief Researcher at Occupational Hygiene and Physiology Department (e-mail: iao_karimova@ rambler.ru; tel.: + 7 (347) 255-57-21).

Pavel V. Serebryakov - Doctor of Medical Sciences, Professor, Head of Therapy Department at Common and Occupational Pathology Institute (e-mail: drsilver@yanndex.ru; tel.: + 7 (495) 582-97-00).

Guzel F. Mukhammadiyeva - Candidate of Biological Sciences, Head of Molecular and Genetic Research Laboratory at Toxicology and Genetics Department (e-mail: ufniimt@ mail.ru; tel.: + 7 (347) 255-19-48). 
$7,12,17,19]$.

A lot of research proves that production aerosols are a risk factor causing occupational bronchitis [3, 4, 9]. Production aerosols tend to contain various components and their complex impacts on respiratory organs together with multiple factors of exogenous and endogenous nature existing at different productions lead to a great variety in clinical signs of occupational bronchitis $[1,13$, $15,18]$.

A human body can possible have an individual response to impacts exerted by occupational environment factors; this response can often be determined by genetic polymorphism of enzymes which participate in biological transformation of xenobiotics, There are scientific papers which prove a contribution made by polymorphic cytochrome P-450 genes and glutathione transferase genes in pathogenetic mechanisms of occupational bronchopulmonary system diseases [8, 14].

Our research goal was to study clinical and hygienic peculiarities of how bronchitis evolved and its clinical course in workers exposed to production aerosols.

Data and methods. We performed a profound examination of 234 patients suffering from occupational bronchitis and treated in the in-patient clinic of Ufimskiy Scientific Research Institute for Occupational Medicine and Human Ecology. All patients were under dynamic observation since they had their diagnosis put; they were workers employed in petrochemical industry, mining, civil engineering, and in construction. We applied sanitary-hygienic techniques, clinical-laboratory techniques, molecular-genetic ones and statistic methods.

Working conditions the examined patients had to function in were assessed as per sanitary-hygienic properties of working conditions provided by Rospotrebnadzor Bashkortostan regional office; the assessment also allowed for results obtained by researchers from Labor Hygiene and Physiology Department of Ufimskiy Scientific Research Institute for Occupational Medicine and Human Ecology. We assessed occupational routes and working period spent under production dust impacts as well as occurrence of such predisposing hazardous factors as air temperature and humidity in a working area and physical loads.

Clinical-laboratory research included a complete blood count, biochemical blood study, microbiological examination of sputum, respiratory organs X-ray study, external respiration (ventilation function) assessment, and cardiac ultrasound. Peripheral blood parameters were assessed via electronic-pulse calculation of blood cells with "Sysmax" hematologic automatic analyzer (Japan). To assess intensity of free radical lipid oxidation, we detected malonic dialdehyde in blood serum via spectrophotometry. We performed a general sputum analysis, as well as analyzed it as per microflora content and its sensitivity to antibiotics. External respiration function was examined via computer flowmetry with "Spirolab II" spirometer.

The examined patients suffering from occupational bronchitis were divided into two groups depending on a production aerosol structure and nature:

Group I was made of patients with toxic-dust bronchitis caused by a production aerosol which contained toxic and/or allergenic compounds dust (140 people). Group II were patients suffering from dust bronchitis caused by weakly fibrogenic dust with low allergenic metals content (94 people). Males vs. females ratio amounted to $68 \%$ and $32 \%$ in group I, and $75 \%$ and $25 \%$ in group II correspondingly. Average age at 
which occupational bronchitis was detected was 46.76 \pm 7.72 . Age and working period didn't have any significant discrepancies in both groups. 156 healthy workers employed at an ore mining and processing plant with working period under hazardous conditions equal to 10 years were included into our reference group; they all didn't have respiratory organs pathology in their case history and were considered to be fit for further employment at their working places. Working period under hazardous conditions amounted to $13.28 \pm 6.6$ years, and average age was $43.37 \pm 0.55$ years.

All the examined patients from groups I and II were combined and then divided into smokers and non-smokers. Active smokers group comprised 112 people (47.9\%), and ex-smokers group was made up of 41 (17.5\%). 122 people were non-smokers (52.1\%). A smoker's index was calculated for each smoker.

Molecular and genetic research was performed on 131 patients suffering from occupational bronchitis and on 156 healthy workers form the reference group. DNA was extracted as per a conventional technique of phenol-chloroform extraction [16]. We applied polymerase chain reaction of DNA synthesis to analyze polymorphic types of the first xenobiotics biotransformation phase genes (A2455G of CYP1A1 gene, C1053T of CYP2E1 gene, A415G of EPHX1 gene) and the second xenobiotics biotransformation phase genes (GSTM1, GSTT1 and GSTP1 genes). 53 people with dust bronchitis and 78 people with toxicdust bronchitis were included into an occupational patients group. All the patients were distributed into three groups as per their diseases severity: mild disease (38), average severity (21) and severe disease (72).
We performed mathematical processing with "Stitistica v.6.6" software («StatSoft»), and MS Office Excel 2007 applying Student's t-criterion, $\chi 2$ criterion with Yates correction for fourfold tables, and Fischer's criterion. Dependencies were estimated as per odds ratio, (OR).

Results and discussion. Basing on the performed complex of clinical and hygienic research we detected that toxic-dust bronchitis evolvement was related to long-term exposure of workers employed in petrochemistry, chemical industry, and at welding workshops (average working period $22.65 \pm 0.54$ ) to production aerosols containing dust of toxic and/or allergenic compounds in concentrations which were 6-11 times higher than MPC (hazard class 3.33.4) together with unfavorable microclimate, in-plant noise, and labor process hardness (hazard class 3.1-3.2).

Dust bronchitis evolved due to exposure to weakly fibrogenic dust (average working period 22.61 \pm 0.53 ) which contained $6-8 \%$ of silicone dioxide. Patients suffering from dust bronchitis were mostly workers employed in underground pyrite ore mining and personnel of engineering workshops at civil engineering enterprises. Exposure to dust in concentrations 7-12 times higher than MPC (hazard class 3.33.4) when working period was long was frequently combined with negative impacts exerted by vibrations, noise, and unfavorable microclimate, and with physical loads (hazard class 3.1-3.2).

When analyzing complaints we revealed that cough prevailed among them all in each patient: $29.5 \%$ had non-productive cough, $45.7 \%$ had cough with mucoid sputum, $24.8 \%$ had cough with mucopurulent sputum. $25.6 \%$ complained on dyspnea during intensive exercise and fast walking, $50.4 \%$ had it during moderate exercise, $9 \%$ 
had it even at rest, and only $14.9 \%$ patients didn't have such complaints. $34.2 \%$ patients had occasional wheezing and apparent dyspnea. $52.1 \%$ patients from group II and $41.4 \%$ patients from group I had mucoid sputum $(\chi 2=15.1 ; \mathrm{p}=0.0007 ; \mathrm{df}=1)$. Mucopurulent sputum was more frequently detected in patients from group I $(30.7 \%)$ than from group II $(16.0 \%)(\chi 2=5.80 ; \mathrm{p}=0.017$; $\mathrm{df}=1)$. Clinical and functional deviations grew as the disease progressed and complications occurred. Objective signs corresponded to a stage of the disease. patients groups were comparable in terms of breathing disorders gravity and repeatability of complaints.

As we examined external respiration functions and applied x-ray diagnostics in the examined patients' groups we revealed signs of bronchopulmonary obstruction and lung emphysema in $62 \%$ patients and it gave us grounds to diagnose chronic obstructive lung disease. $38 \%$ of the examined patients had chronic non-obstructive bronchitis, $37.2 \%$ had diffuse pulmonary fibrosis, $24.8 \%$ had pulmonary hypertension signs. We detected radiological changes of cellular type which were characteristic for bronchictasia in $26.9 \%$ cases. Patients from group I had bronchictasia $(\chi 2=4.19 ; \mathrm{p}=0.04$; $\mathrm{df}=1)$ and chronic pulmonary heart $(30.0 \%$ against $17.02 \%$ ) authentically more frequently than patients from group II $(\chi 2$ $=4.410 ; \mathrm{p}=0.03 ; \mathrm{df}=1$ ).

Patients suffering from occupational bronchitis had increased leucocytes, stab neutrophils, monocytes, and ESR in 38\% cases; they had dysproteinemia (hypoalbuminaemia mostly due to increased $\alpha 2-, \beta$ globulins contents) in $18 \%$ cases.

Our research on free radical processes activity in patients groups I and II revealed increased intensity of lipid peroxidation which was 2.3 times higher than in the reference group $(\mathrm{p}<0.001)$ (Table1).

Table 1

Lipid peroxidation products levels in patients groups I and II, $M \pm m$

\begin{tabular}{|l|c|c|c|}
\hline Parameter & Group I & Group II & $\begin{array}{c}\text { Reference } \\
\text { group }\end{array}$ \\
\hline Malonic & $5,53 \pm$ & $5,47 \pm$ & $2,42 \pm$ \\
dialdehyde, & $\begin{array}{c}5,7^{*} \\
\mu \mathrm{mol} / \mathrm{l}\end{array}$ & $\begin{array}{c}* \\
\text { ( }\end{array}$ & 0,04 \\
\hline
\end{tabular}

Note: $*$ - validity of discrepancy with the reference group $(p<0.001)$.

Patients suffering from occupational bronchitis tended to have greater lipid peroxidation activity estimated as per malonic dialdehyde contents as they working experience became longer.

As we performed microbiological examination of sputum we revealed that $74.8 \%$ patients with occupational bronchitis had mostly bacterial microflora consisting of 2-4 component associations.

Bacteria from Staphylococcus $(75.1 \%)$ stem and Streptococcus (62.6\%) stem prevailed among microorganisms detected in patients. Bacteria from Enterobacteriacea family and gram-negative nonfermentative bacteria were less frequently detected, in 18.7 and $13.8 \%$ patients correspondingly.

The greatest number of people with diagnostically significant seeding was detected in patients' group I where such bacteria as Kl. pneumoniae occurred 3.4 times more frequently than in group II; fungi Candida from stem, 2.7 times more frequently, and Br. Catarrhalis, 2.5 times more frequently (Figure 1).

Smoking as an independent factor can make a substantial contribution into chronic bronchitis development in people exposed to production aerosols [10, 11, 20]. 


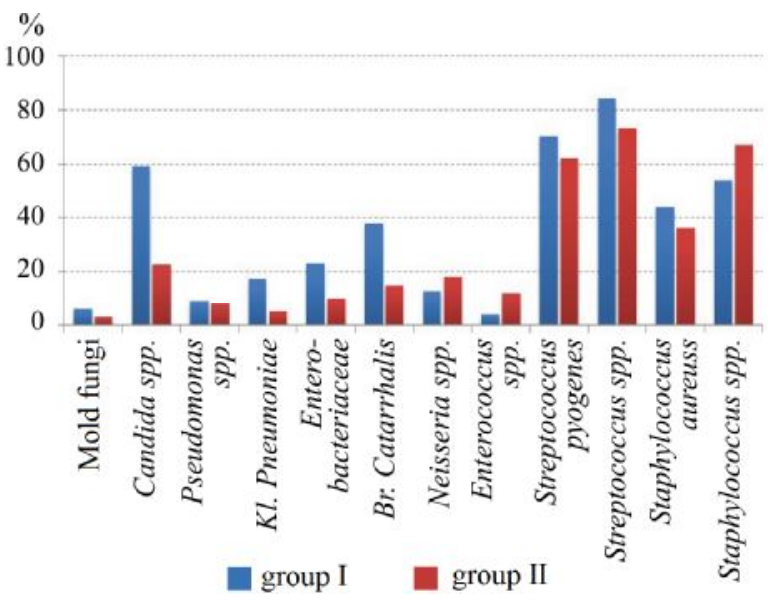

Figure 1. Microflora seeded from sputum of the examined patients from groups I and II, \%

We analyzed ventilation disorders in patients depending on their smoker status allowing for an important contribution made by smoking in chronic bronchitis genesis. Non-smokers prevailed among patients suffering from occupational bronchitis with I degree of respiratory failure. Smokers and ex-smokers much more frequently had grave chronic bronchitis with apparent respiratory failure of II-III degree. Respiratory failure became more grave as a smoker index grew.

As most occupational factors are polytropic and workers are under combined exposure to several hazardous factors it determines frequent occurrence of associated diseases in patients suffering from occupational bronchitis.

$19.2 \%$ examined patients had associated occupational pathology in other organs and systems; $9.4 \%$ of them had three occupational diseases, and $1.7 \%$ suffered from even four of them. As a rule, such diseases evolved in workers with long-term working experience (more than 20 years) and they tended to develop gradually and become chronic. Sensorimotor system pathology prevailed in the morbidity structure and it was mostly represented by vegetativesensory polyneuropathy $(13.25 \%)$, chronic lumbosacral radiculopathy $(3.0 \%)$, scapulo- humeral periarthrosis (3.8\%), and humeral epicondylitis (1.3\%). Occupational ENTorgans pathology was detected in $5.0 \%$ patients (sensorineural hearing loss and allergic rhinitis).

We performed a retrospective analysis of medical files on 82 patients suffering from occupational bronchitis (852 case histories) with observation period over each patient being longer than 10 years. The analysis revealed authentic deterioration of all the ventilation parameters by the end of the examined period with transformation into obstructive and restrictive-obstructive disorders.

When patients had their first examination in a medical-social examination office we detected significant specific weight of disability $(61.5 \%$ patients with toxic-dust bronchitis and $40 \%$ with dust bronchitis), $19.2 \%$ patients from group I and $20.0 \%$ patients from group II had the 2 nd degree disability; $42.3 \%$ and $20.0 \%$ correspondingly had the 3rd degree disability. By the end of the examined period (after 10 years) a share of people with confirmed disability grew by $11.6 \%$ in group I and by $26.7 \%$ in group II. We should note that a number of people with more grave disability (2nd degree) increased by $23.1 \%$ in group I and by $6.7 \%$ in group II.

We compared patients with occupational bronchitis and healthy workers in order to identify genotypes associated with predisposition to bronchopulmonary system failures. We didn't reveal any substantial discrepancies between the overall sampling of people with occupational bronchitis and the reference group as per polymorphic locuses of CYP2E1, GSTM1 and GSTT1 genes

We detected statistically significant increase up to $23.7 \%$ in $* 2 \mathrm{C}$ allele of $\mathrm{A} 2455 \mathrm{G}$ polymorphic variant of CYP1A1 gene in healthy workers in comparison with $13.5 \%$ in people with occupational bronchitis $(\chi 2=7.05 ; p=0.009)$, and it marked their re- 
sistance to the disease $(\mathrm{OR}=0.50 ; 95 \% \mathrm{CI}$ 0.30-0.84).

Examination of frequencies distribution for microsomal epoxide hydrolase (EPHX1) gene phenotypes revealed increase up to $20.5 \%$ in frequency of fast microsomal epoxide hydrolase phenotype among health workers in comparison with $10.9 \%$ among patients with occupational bronchitis $(\chi 2=4.18 ; \mathrm{p}=0.041)$ which can mean that people with fast epoxide hydrolase phenotype have greater adaptability. So, fast phenotype of T337C polymorphic variant of EPHX1 gene is in this case a resistance factor which reduces risks of occupational bronchitis evolvement $\quad(\mathrm{OR}=0.47 ; 95 \% \mathrm{CI}$ 0.23-0.97).

Analysis of $\mathrm{A} 313 \mathrm{G}$ polymorphic variant of GSTP1 gene revealed increase up to $45.5 \%$ in $* A * G$ heterozygote genotype in healthy workers in comparison with $31.2 \%$ in patients with occupational bronchitis $(\chi 2=5.38 ; \mathrm{p}=0.021)$. Presumably $* \mathrm{~A} * \mathrm{G}$ genotype is a marker showing resistance to occupational bronchitis evolvement $(\mathrm{OR}=0.54$; 95\%CI 0.32-0.92) (Table 2).

Table 2

Frequencies distribution for $\mathrm{A} 313 \mathrm{G}$ polymorphic variant of GSTP1 gene in patients with occupational bronchitis and in the reference group

\begin{tabular}{|c|c|c|c|c|c|c|}
\hline \multirow{2}{*}{ Genotype } & \multicolumn{2}{|c|}{$\begin{array}{c}\text { Patients with } \\
\text { occupational } \\
\text { bronchitis }\end{array}$} & \multicolumn{2}{|c|}{$\begin{array}{c}\text { Reference } \\
\text { group }\end{array}$} & \multirow{2}{*}{$\chi^{2}$} & \multirow{2}{*}{$p$} \\
\cline { 2 - 6 } & $n$ & $\%$ & $n$ & $\%$ & & \\
\hline$* A^{*} A$ & 75 & 60,0 & 79 & 50,6 & 2,09 & 0,149 \\
\hline$* A^{*} G$ & 39 & 31,2 & 71 & 45,5 & 5,38 & 0,021 \\
\hline${ }^{*} G^{*} G$ & 11 & 8,8 & 6 & 3,9 & 2,19 & 0,139 \\
\hline
\end{tabular}

We performed comparative analysis of frequencies distribution for genotypes and polymorphic locuses alleles of CYP2E1, EPHX, GSTM1, GSTT1 genes in groups of patients with toxic-dust bronchitis and dust bronchitis and didn't reveal any significant discrepancies. Frequency of $* 1 \mathrm{~A} * 2 \mathrm{C}$ genotype of CYP1A1 gene A2455G polymorphic variant was more than 2 times lower among patients with toxic-dust bronchitis $(10.4 \%)$ in comparison with the reference group $(23.7 \%)(\chi 2=4.23 ; \mathrm{p}=0.039 ; \mathrm{df}=1)$, which was a marker showing resistance to toxicdust bronchitis evolvement $(\mathrm{OR}=0.37$; 95\%CI 0.14-0.96).

Comparison of toxic-dust and dust bronchitis based on the analysis of polymorphic variants of microsomal monooxygenase system genes and antioxidation protection genes showed a basic similarity of occupational bronchitis pathogenesis which occurred due to weakly fibrogenic dust inhalation and due to inhalation of a production aerosol with complicated structure including generally toxic substances and sensitizing substances.

Analysis of $\mathrm{A} 2455 \mathrm{G}$ polymorphic variant of CYP1A1 gene in groups of patients with various clinical course revealed that $* 1 \mathrm{~A} * 2 \mathrm{C}$ heterozygote genotype of $\mathrm{A} 2455 \mathrm{G}$ polymorphic variant of CYP1A1 gene was detected in $35.3 \%$ patients with mild disease severity, in $22.2 \%$ patients with average disease severity, and in $12.5 \%$ patients with severe disease and it wasn't at all detected in patients with extremely severe disease $\left(\chi^{2}\right.$ $=13.89 ; \mathrm{p}=0.031 ; \mathrm{df}=6)$ (Figure 2).

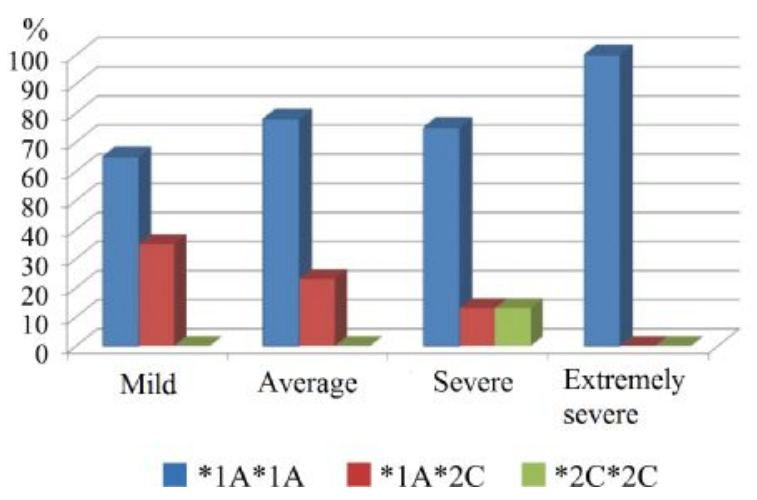

Figure. 2. Frequencies distribution for genotypes of $\mathrm{A} 2455 \mathrm{G}$ polymorphic variant of CYP1A1 gene in patients from group II depending on diseases severity 
CYP1A $1 * 1 \mathrm{~A} * 2 \mathrm{C}$ heterozygote genotype can be considered a protective factor in relation to bronchitis evolvement in the group of patients suffering from toxic-dust bronchitis.

So, our research allowed us to detect that a nature of evolving occupational bronchitis and peculiarities in its clinical picture were determined not only by hazardous occupational factors but also by individual peculiarities of a patient. Due to our examining polymorphism of xenobiotics biotransformation enzymes genes we revealed genetic markers associated with workers' resistance to occupational bronchitis.

\section{Conclusions:}

1. Workers employed in the examined economic branches had to function in working conditions characterized with prevailing exposure to production aerosols with complicated structure corresponding to 3.2-.4 hazard class. Workers employed at petrochemical and chemical enterprises and at welding workshops mostly suffered from toxic-dust bronchitis caused by exposure to a production aerosol with complicated structure containing generally toxic, sensitizing and irritating dust; workers employed in mining and civil engineering suffered from so called dust bronchitis caused by exposure to weakly fibrogenic dust with low allergenic metals content as opposed to group I.

2. Occupational bronchitis in workers exposed to production aerosols had a number of peculiarities: the diseases tended to progress which led to early disablement due to obstructive-restrictive disorders growth, prompt occurrence of various infections, and grave complications including pulmonary heart.

3. We detected hyperactivation of free radical oxidation processes under longterm exposure to production aerosols; we also detected authentic increase in lipid peroxidation products as working experience under hazardous conditions grew.

4. There are protective markers in relation to occupational bronchitis evolvement. They are $* 2 \mathrm{C}$ allele of $\mathrm{A} 2455 \mathrm{G}$ polymorphic variant of CYP1A1 gene, AG genotype of $\mathrm{A} 313 \mathrm{G}$ polymorphic variant of GSTP1 gene, and fast phenotype of T337C polymorphic variant of EPHX1 gene. $* 1 \mathrm{~A} * 2 \mathrm{C}$ genotype of $\mathrm{A} 2455 \mathrm{G}$ polymorphic variant of CYP1A1 gene is associated with milder clinical course of dust bronchitis.

5 . We present a set of informative molecular-genetic and biochemical markers which can be used in assessing risks of occupational bronchitis evolvement and in individual forecasts for the disease clinical course.

\section{References}

1. Shpagina L.A., Poteryaeva E.L., Kotova O.S., Shpagin I.S., Smirnova E.L. Aktual'nye problemy pul'monologii $\mathrm{v}$ sovremennoi profpatologicheskoi klinike [Topical problems of pulmonology in contemporary occupational medicine]. Meditsina truda i promyshlennaya ekologi$y a, 2015$, no. 9, pp. 11-14 (in Russian).

2. Babanov S.A., Budash D.S. Kliniko-laboratornye osobennosti i prognozirovanie techeniya khronicheskogo pylevogo bronkhita, silikoza i pnevmokonioza ot vozdeistviya svarochnykh aerozolei [Clinical and laboratory peculiarities and forecasts for development of chronic dust bronchitis, silicosis and pneumoconiosis caused by exposure to welding aerosols]. Sanitarnyi vrach, 2016, no. 4, pp. 37-47 (in Russian). 
3. Beigel' E.A., Katamanova E.V., Shayakhmetov S.F., Ushakova O.V., Pavlenko N.A., Kuks A.N., Voronin D.A. Vliyanie dlitel'nogo vozdeistviya promyshlennykh aerozolei na funktsional'noe sostoyanie bronkholegochnoi sistemy u rabotnikov alyuminievogo proizvodstva [The impact of the long-term exposure of industrial aerosols on clinical and functional indices of the broncho-pulmonary system in aluminum smelter workers]. Gigiena i sanitariya, 2016, no. 12, pp. 1160-1163 (in Russian).

4. Professional'nye zabolevaniya organov dykhaniya: natsional'noe rukovodstvo [Occupational diseases of respiratory organs: national guide]. In: N.F. Izmerov, A.G. Chuchalin, eds. Moscow, GEOTAR-Media Publ., 2015, 792 p. (in Russian).

5. Izmerov N.F., Kuz'mina L.P., Kolyaskina M.M., Lazarashvili N.A. Molekulyarnogeneticheskie issledovaniya $\mathrm{v}$ meditsine truda [Molecular genetic studies in occupational medicine]. Gigiena i sanitaria, 2011, no. 5, pp. 10-14 (in Russian).

6. Shpagina L.A., Voevoda M.I., Kotova O.S., Maksimov V.N., Orlov P.S., Shpagin I.S., Gerasimenko O.N., Bobrov S.V. Professional'naia khronicheskaia obstruktivnaia bolezn' legkikh s pozitsii molekuliarno-geneticheskikh issledovanii [Occupational chronic obstructive pulmonary disease from the point of molecular genetic research]. Biulleten' fiziologii i patologii dykhaniia, 2013, no. 49, pp. 8-15. (in Russian).

7. Gafarov N.I., Zakharenkov V.V., Panev N.I., Kucher A.N., Freidin M.B., Rudko A.A. Rol' geneticheskikh faktorov $\mathrm{v}$ razvitii khronicheskogo pylevogo bronkhita u rabotnikov ugledobyvaiushchikh predpriiatii Kuzbassa [The role of genetic factors in the development of chronic dust bronchitis in workers of coal mining enterprises of Kuzbass]. Gigiena i sanitaria, 2013, no. 4, pp. 44-47. (in Russian).

8. Kuz'mina L.P., Kolyaskina M.M., Lazarashvili N.A., Bezrukavnikova L.M., Izmerova N.I., Sanin V.Yu., Petinati Ya.A., Tsidil'kovskaya E.S., Pomykanova Yu.S., Chistova I.Ya. Sovremennye meditsinskie tekhnologii $\mathrm{v}$ diagnostike $\mathrm{i}$ otsenke riska razvitiya professional'nykh zabolevanii [Contemporary medical technologies in diagnosis and evaluating risk of occupational diseases]. Meditsina truda i promyshlennaya ekologiya, 2013, no. 7, pp. 9-13 (in Russian).

9. Shayakhmetov S.F., Lisetskaya L.G., Merinov A.V. Otsenka toksiko-pylevogo faktora v proizvodstve aliuminiia (analiticheskii obzor) [Evaluation of toxic dust factor in aluminium production (analytic review)]. Meditsina truda i promyshlennaya ekologiya, 2015, no. 4, pp. 30-35. (in Russian).

10. Shilov V.V., Syurin S.A. Vliyanie kureniya i proizvodstvennykh aeropollyutantov na respiratornoe zdorov'e rabotnikov nikelevoi promyshlennosti [Influence of smoking and industrial air pollutants on respiratory health of nickel industry workers]. Meditsina truda i promyshlennaya ekologiya, 2015, no. 11, pp. 40-44 (in Russian).

11. Bobrov S.V., Shpagina L.A., Kuznetsova G.V., Burganova M.R. Effektivnost' rannei diagnostiki i profilaktiki khronicheskoi obstruktivnoi bolezni legkikh u rabotnikov promyshlennykh predpriyatii (rezul'taty prospektivnogo nablyudeniya) [Efficiency of early diagnosis and prevention of chronic obstructive pulmonary disease in industrial workers (prospective observation results)]. Meditsina truda i promyshlennaya ekologiya, 2011, no. 10, pp. 6-10 (in Russian).

12. Yang L., Li F., Yan M., Su X. Association of the CYP1A1 MspI and TNF $\alpha-308$ polymorphisms with chronic obstructive pulmonary disease in Inner Mongolia. Genet. Mol. Res., 2014, vol. 13, no. 2, pp. 3209-3217.

13. Mazitova N.N., Saveliev A.A., Berheeva Z.M., Amirov N.Kh. COPD and occupation: a retrospective cohort study of industrial workers. Arh. Hig. Rada Toksikol., 2012, vol. 63, no. 3, pp. 345-356. 
14. Dubovskaya L.V., Rybina T.M., Bakakina Y.S., Kardash O.F., Denisevich N.P., Volotovski I.D. Genetic Predisposition to Chronic Dust Bronchitis among Potash Miners. J. Med. and Biol. Sci. Res., 2015, vol. 1, no. 6, pp. 55-61.

15. Rodríguez E., Ferrer J., Zock J.P., Serra I., Antó J.M., de Batlle J., Kromhout H., Vermeulen R., Donaire-González D., Benet M., Balcells E., Monsó E., Gayete A., Garcia-Aymerich J. PAC-COPD Study Group. Lifetime occupational exposure to dusts, gases and fumes is associated withbronchitis symptom and higher diffusion capacity in COPD patients. PLoS One, 2014, vol. 9, no. 2, e88426.

16. Mathew C.C. The isolation of high molecular weight eucariotic DNA. In: Walker J.M., Ed. Methods in molecular biology. N.Y.: Haman press, 1984, pp. 31-34.

17. Omland O., Würtz E.T., Aasen T.B., Blanc P., Brisman J.B., Miller M.R., Pedersen O.F., Schlünssen V., Sigsgaard T., Ulrik C.S., Viskum S. Occupational chronic obstructive pulmonary disease: a systematic literature review. Scand. J. Work Environ. Health, 2014, vol. 40, no. 1 , pp. 19-35.

18. Doney B., Hnizdo E., Graziani M., Kullman G., Burchfiel C., Baron S., Fujishiro K., Enright P., Hankinson J.L., Stukovsky K.H., Martin C.J., Donohue K.M., Barr R.G. Occupational risk factors for COPD phenotypes in the Multi-Ethnic Study of Atherosclerosis (MESA) Lung Study. COPD, 2014, vol. 11, no. 4, pp. 368-380.

19. Mehta A.J., Miedinger D., Keidel D., Bettschart R., Bircher A., Bridevaux P.O., Curjuric I., Kromhout H., Rochat T., Rothe T., Russi E.W., Schikowski T., Schindler C., Schwartz J., Turk A., Vermeulen R., Probst-Hensch N., Künzli N.; SAPALDIA Team. Occupational exposure to dusts, gases, and fumes and incidence of chronic obstructive pulmonary disease in the Swiss Cohort Study on Air Pollution and Lung and Heart Diseases in Adults. Am. J. Respir. Crit. Care Med., 2012, vol. 185, no. 12, pp. 1292-1300.

20. Rushton L. Occupational causes of chronic obstructive pulmonary disease. Rev. Environ. Health, 2007, vol. 22, no. 3, pp. 195-212.

Bakirov A.B., Mingazova S.R., Karimova L.K., Serebryakov P.V., Mukhammadieva G.F. Risk of dust bronchopulmonary pathology development in workers employed in various economic brunches under impacts exerted by occupational risk factors: clinical and hygienic aspects. Health risk Analysis, 2017, no. 3, pp. 83-91. DOI: 10.21668/health.risk/2017.3.10.eng

Received: 24.05 .2017

Accepted: 16.08.2017

Published: 30.09.2017 